\title{
Prediksi Harga Saham Perusahaan Operator Telekomunikasi Selular pada Masa Pandemi Menggunakan Metode Binomial
}

\author{
Ferliana*, Yani Ramdani \\ Prodi Matematika, Fakultas Matematika dan Ilmu Pengetahuan Alam, \\ Universitas Islam Bandung, \\ Jl. Tamansari No. 1 Bandung 40116 \\ Email: ${ }^{1}$ ferliana784@gmail.com, ${ }^{2}$ yaniramdani66@gmail.com,
}

\begin{abstract}
The corona virus causes all activities to be carried out online so that all activities require Internet access which makes mobile telecommunications operator companies one of the promising investments in this pandemic. Stock investing allows investors to get profits in a relatively short time. Investments in stocks are currently unstable, as the whole world has been in difficult times since the coronavirus. Capital market players can feel the loss, which causes share prices to tend to decline. The impact of the corona virus is to paralyze all areas, especially the economy, so that an investor must be able to predict an increase or decrease in stock prices. The binomial method helps investors to predict the possibility of a stock price that will occur and is clarified by using a binomial tree that can be predicted in the form of stock prices by having the possibility of four predictions, two predictions describing an increase in shares and two other predictions describing the possibility of a falling stock price.
\end{abstract}

Keywords: Investment, Corona Virus, Investors, Stocks, Binomial Method.

\begin{abstract}
Abstrak. Virus korona menyebabkan semua kegiatan dilakukan melalui daring (online) sehingga semua kegiatan memerlukan akses Internet yang membuat perusahaan operator telekomunikasi seluler menjadi salah satu investasi yang menjanjikan dimasa pandemi ini Investasi ialah komitmen menempatkan sejumlah dana dalam waktu yang cukup lama untuk memperoleh keuntungan di masa datang. Investasi saham memungkinkan investor mendapatkan keuntungan dalam waktu yang relatif singkat. Investasi dalam bentuk saham pada saat ini tidaklah stabil, karena seluruh dunia dalam masa sulit semenjak adanya virus korona. Kerugianpun dapat dirasakan oleh pelaku pasar modal yang menyebabkan harga saham cenderung menurun. Dampak virus korona adalah melumpuhkan segala bidang terutama perekonomian sehingga sebagai seorang investor harus bisa memprediksi peningkatan atau penurunan harga saham. Metode binomial membantu investor untuk memprediksi kemungkinan harga saham yang akan terjadi dan diperjelas dengan menggunakan pohon binomial hasil prediksi yang di dapat berupa harga saham dengan memiliki kemungkinan empat prediksi dua prediksi menggambarkan kenaikan saham dan dua prediksi lain menggambarkan kemungkinan harga saham turun.
\end{abstract}

Kata kunci : Investasi, Virus Korona, Investor, Saham, Metode Binomial. 


\section{A. Pendahuluan}

Virus korona atau (pandemi covid-19) kini mewabah keseluruh dunia membuat pemerintah memberikan himbawan untuk tetap berada di rumah dan menghentikan seluruh kegiatan yang mengumpulkan masa dengan jumlah banyak. Hal ini menyebabkan semua kegiatan dilakukan melalui daring (online) sehingga semua kegiatan memerlukan akses Internet yang membuat perusahaan operator telekomunikasi seluler menjadi salah satu investasi yang menjanjikan dimasa pandemi ini.

Investasi merupakan penempatan sejumlah dana yang bertujuan untuk meperoleh keuntungan di masa datang. Investasi sebagai komitmen menanamkan dana pada satu atau lebih asset dalam waktu yang lama [1]. Investasi merupakan komitmen untuk menyisihkan dana yang dimiliki hari ini dengan tujuan memperbesar dana di masa datang [2]. Sehingga investasi merupakan komitmen penempatan sejumlah dana dalam waktu yang cukup lama dengan tujuan untuk memperoleh keuntungan di masa datang.

Untuk saat ini investasi yang banyak diminati karena memungkinkan mendapatkan keuntungan dengan jumlah besar dan dalam waktu singkat adalah investasi saham. Dalam saham, investor bisa memilih dengan bebas saham yang ingin dibeli atau dijual. Saat ini data dari Bursa Efek Indonesia (BEI) terdaftar 708 emiten (perusahaan). Dari 708 emiten yang terdaftar yang akan di bahas dalam skripsi ini mengenai saham perusahan Oprator Telekomunikasi Seluler yaitu PT. XL Axiata.Tbk (EXCL), PT. Telekomunikasi Indonesia.Tbk (TLKM), PT. Indosat.Tbk (ISAT). Dipilihnya saham operator telekomunikasi berdasarkan peluang yang cukup terlihat dengan jelas dimana saat terjadinya pandemic masyarakat dihimbau untuk tetap diam dirumah dan melakukan semua kegiatan dari rumah. Perusahaan operator telekomunikasi seluler memiliki banyak bisnis perusahaan yang dijalankan yang salah satunya memasarkan akses internet [3].Maka dari itu, pemilihan saham operator telekomunikasi seluler cocok unuk dipilih dalam penelitian ini.

Kerugian pun dapat dirasakan oleh para pelaku pasar modal saham yang dimana saat awal munculnya covid-19 serta diberlakukannya anjuran dari pemerintah untuk tetap diam di rumah, sehingga semua kegiatan terhenti yang berakibat banyak saham yang mengalami penurunan harga secara serentak yang diakibatkan dari panic salling diakibatkan rasa khawatir dari para pelaku pasar saham itu sendiri [4].

Melihat kondisi tersebut, sebagai investor harus lebih teliti dalam mengambil keputusan untuk mengambil tindakan saat membeli atau menjual. Menghitung peluang saham menggunakan perhitungan yang tepat mampu meminimalisir terjadinya kerugian di masa pandemi ini. Metode binomial digunakan di eropa sebagai salah satu cara tercepat untuk menentukan pergerakan saham dengan mengasumsikan kemungkinan yang ada untuk mengetahui kemungkinan pergerakan saham di masa datang. Dari kemungkinan yang ada sehingga dapat menjadi tolak ukur dalamm menentuan naik turunnya suatu saham.

\section{B. Landasan}

\section{Teori Prediksi}

Prediksi merupakan proses memperkirakan sesuatu yang mungkin terjadi di masa depan berdasarkan informasi masa lalu dan yang dimiliki saat ini, agar memperkecil kesalahan yang dapat terjadi. Prediksi tidak harus memberikan jawaban pasti mengenai kejadian yang akan

Prediksi Harga Saham Perusahaan ... 3 terjadi, melainkan berusaha untuk mencari jawaban yang mungkin atau akan terjadi [5]. Menurut Kamus Besar Bahasa Indonesia, prediksi ialah hasil dari suatu kegiatan memprediksi atau meramal atau memperkirakan nilai yang ada pada masa datang menggunakan data dari masalalu. Prediksi dapat dilakukan berdasarkan dua cara yaitu, metode ilmiah ataupun subjektif. Umumnya berdasarkan pandangan subjektif dengan sudut pandang sendiri .

Peramalan dapat diartikan sebagai suatu prosedur untuk membuat informasi yang faktual tentang situasi sosial masa depan. Ramalan mempunyai tiga bentuk utama yaitu, proyeksi, prediksi dan pemikiran. 
1. Peramalan sebagai suatu proyeksi didasarkan pada ekstrapolasi atas kecenderungan masa lalu, masa kini, masa depan.

2. Peramalan sebagai suatu prediksi didasarkan pada asumsi teoritik yang tegas. Asumsi dapat membentuk hukum teoritis, proposisi teoritis,atau analogi.

3. Ramalan sebagai suatu pemikiran didasarkan pada penilaian yang informatif.

\section{Saham}

Saham merupakan salah satu instrumen pasar modal yang menjanjikan keuntungan tinggi sehingga banyak dilirik oleh para investor. Selain itu, rugi dan untungnya berinvestasi di saham tergantung keputusan sendiri. Saham menurut Sapto [6] merupakan surat berharga yang merupakan instrument bukti kepemilikan atau pernyataan dari individu/institusi dalam suatu perusahaan. Secara umum saham merupakaan bukti pernyataan modal suatu perusahaan. Fahmi [7] berpendapat bahwa saham merupakan suatu instrument pasar modal yang paling diminati oleh investor, karena mampu memberikan tingkat pengembalian yang menarik. Saham adalah kertas yang tercantum dengan jelas nilai nominal, nama perusahaan dan diikuti dengan hak dan kewajiban yang telah dijelaskan aturannya berdasarkan kebijakan perusahan itu sendiri. Dapat disimpulkan bahwa saham merupakan surat berharga yang menjadi bukti kepemilikan seseorang atau badan terhadap perusahaan dengan tercantum nominal dan nama perusahaan tersebut.

\section{Metode Binomial}

Metode binomial merupakan salah satu metode yang sering digunakan dalam perhitungan harga saham.

Model yang digunakan dalam perhitungan yaitu Binomial Pricing Model pada model ini akan berubah dari satu nilai ke nilai lain dari dua kemungkinan yang ada. Misalkan pada harga saham awal $\left(\mathrm{S}_{0}\right)$ terdapat nilai d dan u dimana:

$$
0<d<u
$$

Untuk nilai saham berikutnya yaitu $S_{1}$ akan berkisar antara $S_{0} d$ dan $S_{0} u$.

Khususnya nilai $d$ dan $u$ diambil memenuhi $0<\mathrm{d}<\mathrm{u}$. Sehingga terjadi perubahan nilai $\mathrm{S}_{0}$ ke $\mathrm{dS}_{0}$ yang menunjukan penurunan nilai $\mathrm{S}_{0}$, sedangkan $\mathrm{S}_{0}$ ke $\mathrm{uS}_{0}$ menunjukan terjadinya peningkatan pada $S_{0}$. Pada umumnya d=1/u.

Dalam periode ke dua saham $S_{o}$ akan mempunyai empat kemungkinan. Misalkan nilai saham awal $S_{0}=6, u=2, d=1 / 2$.

\section{Hasil dan Pembahasan}

Berdasarkan data saham yang digunakan dalam penelitian ini diambil dari m.investing.com dan data yang digunakan sebelum pandemi dari tanggal 2 september 2019 hingga 2 Oktober 2019 sedangkan data awal pandemi yang digunakan data dari tanggal 9 maret 2020 hingga 9 april 2020 untuk mengetahui adanya penurunan harga saham yang signifikan di awal pandemi dilakukan perhitungan normalitas dengan menggunakan aplikasi SPSS sebagai berikut : 
Tabel 3.1 tabel normalitas

\begin{tabular}{|l|c|c|c|}
\hline \multirow{2}{*}{} & \multicolumn{3}{|c|}{ Shapiro-Wilk } \\
\cline { 2 - 4 } & statistic & Df & Sig \\
\hline TLKM2019 & .974 & 22 & .804 \\
\hline EXCL2019 & .940 & 22 & .198 \\
\hline ISAT2019 & .872 & 22 & .008 \\
\hline TLKM2020 & .888 & 22 & .017 \\
\hline EXCL2020 & .891 & 22 & .020 \\
\hline ISAT2020 & .920 & 22 & .075 \\
\hline
\end{tabular}

$\mathrm{H}_{0}$ : jika nilai sig $>0.005$ maka $\mathrm{H}_{0}$ ditolak

$\mathrm{H}_{1}$ : jika nilai sig $<0,005$ maka $\mathrm{H}_{0}$ diterima

Karena nilai sig > 0.005 maka data dalam tabel tersebut merupakan data tidak normal sehingga untuk mengetahui adanya perubahan yang signifikan dilakukan uji non- parametrik dengan aplikasi SPSS sebagai berikut :

Tabel 3.2 uji non- Parametrik

\begin{tabular}{|c|rr|rr|rr|}
\hline & $\begin{array}{c}\text { TLKM2020- } \\
\text { TLKM2019 }\end{array}$ & $\begin{array}{l}\text { EXC12020- } \\
\text { EXCL2019 }\end{array}$ & \multicolumn{2}{|l|}{$\begin{array}{l}\text { ISAT2020- } \\
\text { ISAT2019 }\end{array}$} \\
\hline Z & & $-4.108^{\mathrm{b}}$ & & $-4.107^{\mathrm{b}}$ & $-4.107^{\mathrm{b}}$ \\
\hline $\begin{array}{c}\text { Asymp.Sig } \\
\text { (2-tailed). }\end{array}$ & & & & & \\
\hline
\end{tabular}

$\mathrm{H}_{0}$ : tidak ada pengaruh data sebelum dan awal pandemi

$\mathrm{H}_{1}$ : ada pengaruh antara data sebelum dan setelah pandemi

Karena nilai sig.000 $<0,005$ ini berarti adanya perubahan yang signifikan pada data sebelum dan setelah pandemi.

Setelah mengetahui adanya penurunan harga yang signifikan sebelum pandemi dan awal pandemi selanjutnya dilakukan perhitungan menggunakan metode binomial untuk memprediksikan kemungkinan yang terjadi setelah adanya pandemi dengan data awal panemi dengan langkah -langkah sebagai berikut :

1. mencari nilai presentase kenaikan harga saham (u) atau presentase penurunan harga saham (d) menggunakan rumus :

$$
\mathrm{d} \text { atau } \mathrm{u}=\frac{S_{2}}{S_{1} \ldots 1}
$$

dengan ketentuan $0<\mathrm{d}<1<\mathrm{u}$

2. menghitung nilai rata-rata dari presentase kenaikan harga saham (u) atau presentase penurunan harga saham (d) hingga di dapat presentase kenaikan harga saham (u) atau presentase penurunan harga saham $(\mathrm{d})$

3. lalu menghitung Presentase peluang kenaikan saham $\left(\mathrm{P}_{\mathrm{u}}\right)$ dan presentase penurunan haraga saham $\left(\mathrm{P}_{\mathrm{d}}\right)$ sebagai berikut :

$$
P_{u} \text { atau } P_{d}=\frac{\text { banyak data uataud }}{\text { banyak hari kerja }} \ldots 2
$$

4. menghitung nilai harga saham awal dengan menghitung rata-rata dari data saham yang ada.

5. Selanjutnya menghitung nilai pada periode ke satu $\left(S_{1}\right)$ 
6. Untuk menghitung harga saham naik, untuk mrnghitung harga saham turun $S_{1}=u * S_{0} \ldots 3$ $S_{1}=d^{*} S_{0} \ldots 4$

Hasil perhitungan sebelum dan sesudah pandemic covid-19 nampak pada gambar berikut:

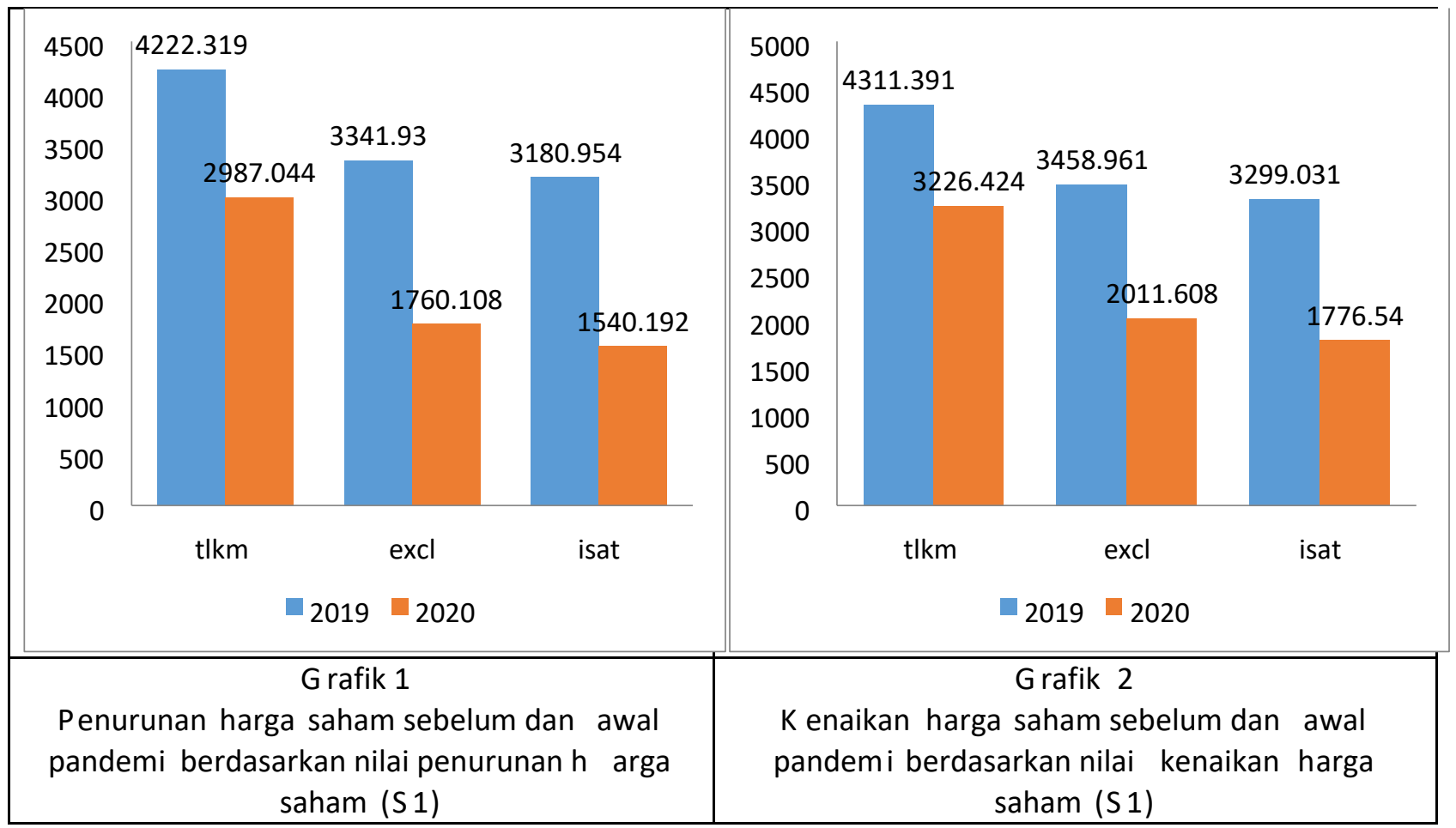

Sehingga diprediksikan setelah pandemi usai pada Saham PT. Telekomunikasi Indonesia,Tbk di memiliki kemungkinan dua kemungkinan pertama harga saham naik sebesar 3226.424 dan bisa jadi naik kembali sebesar 3354.24378 atau bahkan turun menjadi 3105.37859 kemungkinan kedua harga saham turun sebesar 2987.044 bisa jadi naik kembali 3105.37859 atau bahkan turun sebesar 2874.9777438. Pada Saham EXCl juga memiliki dua kemungkinan pertama harga saham naik sebesar 2011.608 dan bisa jadi naik kembali menjadi 2161.628352 atau bahkan turun menjadi 1891.3713077 kemungkinan kedua harga saham turun menjadi 1760.108 bisa jadi naik 1891.3713077 atau bisa jadi turun menjadi 1654.9034715. Pada saham Isat juga memiliki dua kemungkinan pertama harga saham naik seharga 1776.54 dan bisa jadi bertambah naik sebesar 1911.2720913 atau bahkan turun menjadi 1656.9998568 kemungkinan kedua harga saham turun menjadi 1540.192 dan bisa jadi naik menjadi 1656.9998568 atau bahakan turun menjadi 1436.5559128 .

\section{Kesimpulan}

Teknik analisi data pada data awal sebelum pandemi dan sesudah pandemi dilihat hasil penurunan harga saham yang signifikan terbukti melalui perhitungan menggunakan aplikasi SPSS dan di buktikan terjadinya penurunan harga saham di awal pandemi. Setelah di prediksikan sehingga dihasilkan beberapa kemungkinan yang mungkin terjadi seperti yang telah di sebutkan pada hasil dan pembahasan sehingga para investor bisa melihat dengan mudah mengenai kemungkinan- kemungkinan pergerakan harga saham yang akan terjadi dengan lebih jelas. 


\section{Daftar Pustaka}

[1] C. P. J. Jones, Investments Analysis and Management, Gramedia, Jakarta, 2004.

[2] W. F. G. J. A. \&. J. e. V. B. Sharpe, "Investasi," jakarta, PT. Indeks Kelompok, 2005, pp. Edisi Keenam, Jilid I, Edisi Bahasa Indonesia.

[3] A. AZWAR, "Strategi Persaingan Operator Telekomunikasi Seluler," Buletin Pos dan Telekomunikasi, vol. 13, 2015.

[4] R. Octovian, "Lembaga Penelitian dan Pengabdian kepada Masyarakat," GELIAT PASAR MODAL DAN EFEK DOMINO DARI WABAH COVID-19, 2020.

[5] kasmir, Studi Kelayakan Bisnis, Jakarta: Prenada Media, 2003.

[6] S. Rahardjo, Kiat Membangun Aset Kekayaan ( panduan Investasi Saham), Jakarta: PT Alex Media Komputindon, 2006.

[7] I. Fahmi, Pengantar Pasar Modal. Edisi 1, Bandung: Alfabeta, 2012. 